\title{
The Metabolism of Branched-Chain Amino Acids by Starved Rumen Protozoa
}

\author{
Ryoji ONODERA and Yasuki Goto* \\ Animal Nutrition and Biochemistry, Animal Science Division, \\ Faculty of Agriculture, Miyazaki University, \\ Miyazaki-shi $889-21$
}

(Received February 16, 1990)

\begin{abstract}
Regarding essential amino acids (for rat), little have been known about the metabolism of branched-chain amino acids (BCAA), phenylalanine and histidine by rumen ciliate protozoa. Thus isotopic tracer experiments were conducted in this study to examine the metabolism of BCAA such as L-leucine, L-isoleucine and L-valine using a starved mixed rumen protozoal suspension. The starved rumen protozoal suspension prepared from goat rumen contents was incubated in a buffer solution (MB 9) containing ${ }^{14} \mathrm{C}$-labelled BCAA with three kinds of antibiotics using a Warburg flask with a center well to trap $\mathrm{CO}_{2}$ at $39^{\circ} \mathrm{C}$ for $12 \mathrm{hr}$. Before and after incubation, the concentrations of amino acids and volatile fatty acids (VFA) in the centrifuged supernatant fluid of the incubation medium and the concentration of amino acids in protozoal hydrolysates were assayed. Then the radioactivities of these fractions and $\mathrm{CO}_{2}$ fraction were assayed. The protozoal suspension produced carbon dioxide and four- and five-carbon volatile fatty acids from those substrates. Although VFA, especially, branched-chain VFA could not be identified, the results obtained in the present experiments and some results previously reported by other investigators led us to presume that four-carbon VFA was isobutyrate produced from valine and five-carbon VFA were isovalerate and 2-methylbutyrate produced from leucine and isoleucine, respectively. The degradation rates of leucine and isoleucine in the protozoal suspension seemed to be intermediate, while that of valine was slow, compared to those of arginine, threonine and so on reported in previous papers.
\end{abstract}

Jpn. J. Zootech. Sci., 61 (9) : 843-849, 1990

Key words: rumen protozoa, leucine metabolism, valine metabolism, isoleucine metabolism

The fundamental study of the amino acid metabolism of rumen ciliate protozoa is important in understanding their role in the rumen microbial ecosystem and their contribution to the nutrition of their host animals. We have previously reported our studies of the metabolism of lysine ${ }^{7-10)}$, arginine and the related compounds ${ }^{14)}$, methionine and threoni$n \mathrm{e}^{13,15)}$ by mixed rumen ciliate protozoa.

There have been some studies on the metabolism of free branched-chain amino acids
(BCAA) by rumen microorganisms. For example, Bacteroides ruminicola and mixed rumen microbes have been shown to convert leucine, isoleucine and valine to isovalerate, 2-methylbutyrate and isobutyrate, respectively ${ }^{3,6)}$. However there have been no studies on the free BCAA metabolism by rumen protozoa, except those on aminotransferase ${ }^{2,17,18)}$, though COLEMAN $^{5)}$ has reported that Entodinium caudatum produced isovalerate, 2-methylbutyrate and isobutyrate in the medium when Escheri-

* Present address : Miyazaki Kyoritsu Hospital, Miyazaki-shi 880

Jpn. J. Zootech. Sci., 61 (9) : 843-849 
chia coli grown with ${ }^{14} \mathrm{C}$-valine, ${ }^{14} \mathrm{C}$-leucine and ${ }^{14} \mathrm{C}$-isoleucine, respectively, was given to the protozoon.

This paper describes the metabolism of free $\mathrm{BCAA}$ by starved mixed rumen protozoa.

\section{Materials and Methods}

1. Preparation of starved rumen protozoa

Mixed rumen ciliate protozoa were obtained from a ruminally fistulated goat (JapaneseSaanen, castrated, $45 \mathrm{~kg}$ ) fed a ration consisting of haycube $(300 \mathrm{~g})$ and concentrate $(100 \mathrm{~g}$, Chubu-Shiryo, Japan) twice daily (in the morning and the evening). Starved protozoal suspensions were prepared in order to make the mixed protozoa almost bacteria-free by treating them as reported earlier ${ }^{15)}$. The starved protozoal suspensions when used, usually contain $0.1 \mathrm{mg} / \mathrm{m} l$ each of dihydrostreptomycin sulfate, penicillin $G$ potassium and chloramphenicol sodium succinate.

2. Incubation procedure and sample treatment

At first, 4-m $l$ portions of the starved rumen protozoal suspension prepared above were incubated at $39^{\circ} \mathrm{C}$ for $12 \mathrm{~h}$ with given amounts (see Table 1) of ${ }^{14} \mathrm{C}$ - and ${ }^{12} \mathrm{C}-\mathrm{BCAA}$ in Warburg flasks with center wells to which $0.7 \mathrm{~m} l$ of $20 \%$ (w/v) $\mathrm{KOH}$ was added to trap carbon dioxide. As the controls, $4-\mathrm{m} l$ portions of $\mathrm{MB} 9$ buffer solution ${ }^{12)}$ (without protozoa) containing the same three antibiotics mentioned above were incubated under the same conditions. Before and after incubation, samples of the incubation medium were taken and radioactivities of carbon dioxide and ether extracts of supernatant and radioactivities and concentrations of amino acids in the supernatant after being extracted with ether and in the protozoal hydrolysates were assayed in the same manner as in the previous paper ${ }^{15)}$.

Simultaneously, $10-\mathrm{m} l$ portions of the starved protozoal suspension were incubated similarly with given amounts (see Table 1) of ${ }^{14} \mathrm{C}$ and ${ }^{12} \mathrm{C}-\mathrm{BCAA}$ in $100-\mathrm{m} l$ conical flasks with center wells to analyze the concentration and radioactivity of volatile fatty acids (VFA). After incubation, the medium was mixed with $2.5 \mathrm{~m} l$ of $5 \mathrm{~N} \mathrm{H}_{2} \mathrm{SO}_{4}$, left overnight and then treated using the procedure reported previously $^{11)}$.

3. Analytical methods

Amino acids were determined by an automatic amino acid analyzer (AA-100, Sibata Chemical App. Mfg. Co., Ltd., Japan). The drained eluate of a peak of some amino acids, when necessary, was collected, and the radioactivity was determined after the removal of carbon dioxide by flushing it with air as described in the previous report ${ }^{16)}$.

The VFA were analyzed by the method of BEUDING and YALE ${ }^{1)}$ using a Celite column as modified by ONODERA and KANDATSU ${ }^{11)}$.

Radioactivity was determined with a liquid scintillation spectrometer (LSC-903, Aloka Co., Ltd., Japan) as reported previously ${ }^{15)}$.

\section{Results}

According to what has been described previ-

Table 1. Composition of incubation medium

\begin{tabular}{llccc}
\hline & & \multicolumn{3}{c}{ Incubation medium for } \\
\cline { 3 - 5 } Additions & Protozoa & Leucine & Isoleucine & Valine \\
\hline${ }^{14} \mathrm{C}-$ amino acid & With & $1.1^{\mathrm{b}}$ & 0.8 & 0.7 \\
$(\mu \mathrm{Ci} / \mathrm{m} l)$ & Without & 0.8 & 0.8 & 0.8 \\
${ }^{12} \mathrm{C}-$ amino acid & With & 150 & 200 & 200 \\
$(\mathrm{nmol} / \mathrm{m} l)$ & Without & 150 & 200 & 200 \\
\hline
\end{tabular}

a : Specific activity of each branched-chain amino acid is as follows: $\mathrm{L}-\left[\mathrm{U}-{ }^{14} \mathrm{C}\right]$ leucine, $346.0 \mathrm{Ci} / \mathrm{mol}$; $\mathrm{L}-[\mathrm{U}-$ $\left.{ }^{14} \mathrm{C}\right]$ isoleucine, $331.0 \mathrm{Ci} / \mathrm{mol} ; \mathrm{L}-\left[\mathrm{U}^{-14} \mathrm{C}\right]$ valine, $294.0 \mathrm{Ci} / \mathrm{mol}$.

b: For analysis of volatile fatty acids, $1.0 \mu \mathrm{Ci} / \mathrm{ml}$ of leucine was added. 
ously ${ }^{15)}$, a starved rumen protozoal suspension, which has been shown to be almost bacteriafree, was also used in the present experiments. The metabolic activity and the protozoal composition of the suspension usually varied to some extent in every experiment, though the tendencies of the results were consistent. The data presented in this paper, therefore, are the most active out of three trials.

The species and numbers found in the cell suspensions of the starved rumen protozoa used in these experimeots are shown in Table 2 with subfamily names or genus names. More than about $94 \%$ was Entodinium.

When the protozoal suspension was incubated with each radioactive BCAA for $12 \mathrm{~h}$, radioactivities in the carbon dioxide and ether extracts in the supernatant of the medium increased, while those of the supernatant after being extracted with ether decreased (Table 3). Radioactivity in the protozoal hydrolysate also slightly increased after incubation (Table 3 ).

The total amount of leucine, isoleucine and valine in the supernatant and protozoal hydrolysate in each medium decreased by $8.7,15.3$ and $7.3 \%$, respectively, while the concentration of each amino acid in the supernatant increased about 2.6, 2.4 and 1.6 times, respectively (Table 4). The specific activity (SA) of each BCAA in the supernatant declined sharply, whereas the SA of the total (including ciliate hydrolysate) of each BCAA declined moderately (Table 5).

Analysis of VFA in the ether extracts of the medium after $12 \mathrm{~h}$-incubation revealed that radioactive five-carbon VFA was produced from leucine, isoleucine and valine and radioactive four-carbon VFA was also produced from valine (Table 6). Among the VFAs, fourcarbon acid (perhaps mainly butyrate) and acetate showed relatively higher concentrations in these protozoal suspensions.

Table 2. Protozoal composition in the media used in the present experiments

\begin{tabular}{lcccc}
\hline \hline $\begin{array}{c}\text { Incubation } \\
\text { medium } \\
\text { for }\end{array}$ & \multicolumn{3}{c}{ Composition of protozoa $\left(\times 10^{3} / \mathrm{m} l\right)$} \\
\cline { 2 - 5 } & Entodiniinae & Diplodiniinae & Isotricha & Dasytricha \\
\hline Leucine & 512 & 14.2 & 1.4 & 0 \\
Isoleucine & 958 & 57.3 & 4.0 & 1.3 \\
Valine & 394 & 15.7 & 0.3 & 0.3 \\
\hline
\end{tabular}

Table 3. Distribution of radioactivities in general fractions before and after incubation of radioactive branched-chain amino acids with or without starved mixed rumen protozoa (P)

(Unit: $\%$ of the initial radioactivity)

\begin{tabular}{|c|c|c|c|c|c|c|c|}
\hline \multirow[t]{3}{*}{ Fractions } & \multirow{3}{*}{$\begin{array}{l}\text { Incubation } \\
\text { time, (h) }\end{array}$} & \multicolumn{6}{|c|}{ Substrates } \\
\hline & & \multicolumn{2}{|c|}{ Leucine } & \multicolumn{2}{|c|}{ Isoleucine } & \multicolumn{2}{|c|}{ Valine } \\
\hline & & $\underset{\mathrm{P}}{\text { With }}$ & $\begin{array}{l}\text { Without } \\
P\end{array}$ & $\begin{array}{c}\text { With } \\
\mathrm{P}\end{array}$ & $\begin{array}{c}\text { Without } \\
P\end{array}$ & $\begin{array}{c}\text { With } \\
\mathrm{P}\end{array}$ & $\begin{array}{c}\text { Without } \\
\mathrm{P}\end{array}$ \\
\hline \multirow[t]{2}{*}{ Supernatant } & 0 & 97.8 & - & 97.1 & - & 96.5 & $\cdots$ \\
\hline & 12 & 71.0 & 100.3 & 64.3 & 94.5 & 82.7 & 99.7 \\
\hline \multirow[t]{2}{*}{ Carbon dioxide } & 0 & 0 & - & 0 & - & 0 & - \\
\hline & 12 & 5.2 & 0.2 & 0.7 & 0 & 0.5 & 0.1 \\
\hline \multirow{2}{*}{ Ether extracts } & 0 & 4.7 & - & 4.9 & - & 1.5 & - \\
\hline & 12 & 18.3 & 5.5 & 23.5 & 5.0 & 7.1 & 2.5 \\
\hline \multirow{2}{*}{$\begin{array}{l}\text { Hydrolysate } \\
\text { of protozoa }\end{array}$} & 0 & 0 & - & 0.1 & - & 0.1 & - \\
\hline & 12 & 0.3 & - & 1.6 & - & 2.5 & - \\
\hline
\end{tabular}

a : Supernatant fluid after being extracted with ether. 
ONODERA and Goto

Table 4. Change of the concentration $(\mathrm{nmol} / \mathrm{ml})$ of each branched-chain amino acid in each incubation medium

\begin{tabular}{|c|c|c|c|c|c|c|}
\hline \multirow{4}{*}{ Fractions } & \multicolumn{6}{|c|}{ Incubation medium for } \\
\hline & \multicolumn{2}{|c|}{ Leucine } & \multicolumn{2}{|c|}{ Isoleucine } & \multicolumn{2}{|c|}{ Valine } \\
\hline & \multicolumn{3}{|c|}{ (Incubation } & \multirow{2}{*}{$\begin{array}{c}\text { time, } \\
12\end{array}$} & \multicolumn{2}{|l|}{ h) } \\
\hline & 0 & 12 & 0 & & 0 & 12 \\
\hline Supernatant & 133 & 344 & 229 & 557 & 193 & 309 \\
\hline Protozoa & 2025 & 1622 & 2123 & 1435 & 746 & 561 \\
\hline Total & 2158 & 1971 & 2352 & 1992 & 939 & 870 \\
\hline
\end{tabular}

Table 5. Changes of specific activities of branched-chain amino acids during incubation

\begin{tabular}{|c|c|c|c|c|c|}
\hline \multirow{2}{*}{$\begin{array}{l}\text { Amino acid } \\
\text { added }\end{array}$} & \multirow{2}{*}{$\begin{array}{l}\text { Incubation } \\
\text { time, (h) }\end{array}$} & \multicolumn{2}{|c|}{$\begin{array}{l}\text { Specific activity } \\
(\mathrm{dpm} / \mathrm{nmol})\end{array}$} & \multicolumn{2}{|c|}{$\begin{array}{l}\text { Decrement } \\
(\%)\end{array}$} \\
\hline & & $\begin{array}{l}\text { Supernatant } \\
\left(\times 10^{4}\right)\end{array}$ & $\underset{\left(\times 10^{3}\right)}{\text { Total }}$ & Supernatant & Total ${ }^{a}$ \\
\hline \multirow[t]{2}{*}{ Leucine } & 0 & 2.136 & 1.330 & & \\
\hline & 12 & 0.455 & 0.830 & 78.7 & 37.6 \\
\hline \multirow[t]{2}{*}{ Isoleucine } & 0 & 0.732 & 0.720 & & \\
\hline & 12 & 0.177 & 0.570 & 75.8 & 20.8 \\
\hline \multirow[t]{2}{*}{ Valine } & 0 & 0.700 & 1.410 & & \\
\hline & 12 & 0.240 & 0.830 & 65.7 & 41.1 \\
\hline
\end{tabular}

a: Total value includes each corresponding amino acid in protozoal hydrolysate together with that in supernatant.

Table 6. Distribution of radioactivity in volatile fatty acid fractions after $12 \mathrm{~h}$-incubation with radioactive branched-chain amino acids

\begin{tabular}{|c|c|c|c|c|c|c|}
\hline \multirow{3}{*}{$\begin{array}{l}\text { Volatile } \\
\text { fatty } \\
\text { acid } \\
\text { fractions }\end{array}$} & \multicolumn{6}{|c|}{ Amino acid added } \\
\hline & \multicolumn{2}{|c|}{ Leucine } & \multicolumn{2}{|c|}{ Isoleucine } & \multicolumn{2}{|c|}{ Valine } \\
\hline & $\mu \mathrm{mol} / \mathrm{ml}$ & $\begin{array}{r}\mathrm{dpm} / \mathrm{m} l \\
\left(\times 10^{4}\right)\end{array}$ & $\mu \mathrm{mol} / \mathrm{m} l$ & $\begin{array}{c}\mathrm{dpm} / \mathrm{m} l \\
\left(\times 10^{4}\right)\end{array}$ & $\mu \mathrm{mol} / \mathrm{ml}$ & $\begin{array}{r}\mathrm{dpm} / \mathrm{ml} \\
\left(\times 10^{4}\right)\end{array}$ \\
\hline $\mathrm{C}_{5}$-acid & 1.61 & 29.6 & 2.69 & 9.86 & 0.45 & 1.27 \\
\hline $\mathrm{C}_{4}$ acid & 3.42 & 0 & 7.04 & 0 & 0.61 & 3.15 \\
\hline Propionate & 1.47 & 0 & 0.72 & 0 & 0 & 0 \\
\hline Acetate & 6.16 & 0 & 4.20 & 0 & 1.46 & 0 \\
\hline
\end{tabular}

\section{Discussion}

Radioactive BCAA were shown to be metabolized in the starved rumen protozoal suspension to produce common radioactive carbon dioxide and ether-soluble substances (Table 3). Degradation rates $(\mathrm{nmol} / \mathrm{ml} / \mathrm{h})$ of leucine, isoleucine and valine calculated from the total values shown in Table 4 are 15.6, 30.0 and 5.8, respectively (Table 7). As shown in Table 7, arginine $^{14)}$, threonine ${ }^{15)}$ and citrulline ${ }^{14)}$ were indicated to be rapidly degraded in the protozoal suspension and the former two were also shown to be rapidly-degradable even under in vitro and in vivo mixed rumen microbial conditions (Chalupa $)^{4)}$. Therefore degradation rates of isoleucine and leucine in the present experiment were thought to be at an intermediate rank together with ornithine and lysine ${ }^{7)}$, whereas valine was least rapidly degraded. These tendencies almost agreed with the results obtained by the mixed rumen microbial population ${ }^{4)}$. Results of ammonia production by rumen protozoa also showed to include citrulline and 
Table 7. Ammonia production rates from and degradation rates of some amino acids so far tested in in vitro rumen protozoal suspension

\begin{tabular}{lclc}
\hline Amino acid & $\begin{array}{c}\text { Ammonia production } \\
(\mathrm{nmol} / \mathrm{m} / / \mathrm{h})\end{array}$ & Amino acid & $\begin{array}{c}\text { Decrease } \\
(\mathrm{nmol} / \mathrm{m} / / \mathrm{h})\end{array}$ \\
\hline Glutamine $^{\mathrm{a}}$ & 817 & Arginine $^{\mathrm{a}}$ & 75.0 \\
Citrulline $^{\mathrm{a}}$ & 333 & Threonine $^{\mathrm{b}}$ & 20.7 \\
Arginine $^{\mathrm{a}}$ & 267 & Citrulline $^{\mathrm{a}}$ & 60.8 \\
Asparagine $^{\mathrm{a}}$ & 267 & Isoleucine $^{\mathrm{c}}$ & 30.0 \\
Ornithine $^{\mathrm{a}}$ & 100 & Ornithine $^{\mathrm{a}}$ & 20.0 \\
Glutamate $^{\mathrm{a}}$ & 0 & Leucine $^{\mathrm{c}}$ & 15.6 \\
Aspartate $^{\mathrm{a}}$ & 0 & Lysine $^{\mathrm{d}}$ & 15.5 \\
Histidine $^{\mathrm{a}}$ & 0 & Valine $^{\mathrm{c}}$ & 5.8 \\
\hline
\end{tabular}

a: From O NODERA et al. ${ }^{14}$, where ammonia was assayed by Conway's microdiffusion method.

b: From Onodera and Migita ${ }^{15 !}$.

c: Calculated from the values shown in Table 4 in the present experiment.

d: From Ononera and Kandatsu ${ }^{71}$.

arginine in the highest group together with glutamine and asparagine (Table 7).

Decrements $(\%)$ in the total concentrations of leucine, isoleucine and valine after incubation calculated from the values in Table 4 were $8.7,15.3$ and 7.3 , respectively, and were not strictly consistent with the decrements in their radioactivities in the supernatant $(29.0,35.7$ and $17.3 \%$, respectively) calculated from the values in Table 3 . This is because each free BCAA $\left({ }^{12} \mathrm{C}\right)$ can be released from the protozoal protein to the medium as shown in Table 4. Thus the SA of each BCAA in the medium varied with incubation time as shown in Table 5. Namely the SA of each BCAA in the supernatant of the protozoal suspension decreased by about 66 to $79 \%$ after incubation, while the $\mathrm{SA}$ of each of the total BCAA including protozoal hydrolysate decreased by about 20 to 40 $\%$.

Production of carbon dioxide (Table 3) suggests that these BCAA are firstly transaminated (or deaminated) and then decarboxylated like in the case or rumen bacteria ${ }^{3,6}$. Decarboxylated products seemed to appear mainly in ether extracts (Table 3). Chromatographic and radiologic analysis of the ether extracts after incubation revealed that the main radioactive metabolic products were four- and five-carbon VFA (Table 6). Of five-carbon acids, those produced from leucine and isoleucine were pre- sumed to be isovalerate and 2-methylbutyrate, respectively, from the results with washed suspension of mixed rumen microbes ${ }^{6)}$ and with Bacteroides ruminicola ${ }^{3)}$, though we could not identify them in the present experiment. A five-carbon acid produced from valine may probably be 2-oxoisovalerate, as DEHORITY et al. ${ }^{6)}$ pointed out, though we are not sure whether the oxo-acid appear in this five-carbon VFA fraction in the Celite column fractionation method ${ }^{1,11}$. A four-carbon VFA produced from valine may be isobutyrate like in the case in mixed rumen microbes ${ }^{6}$.

Protozoal cells incorporated radioactive substances from BCAA to some extent. This reflects the turnover of protein in the starved protozoal cells.

\section{Acknowledgement}

The authors are grateful to Dr. H. OGAwA, Associate Professor, Miyazaki University, for inserting a permanent rumen fistula in a goat. This work was financially supported by the Radioisotope Center, Miyazaki University.

This report is part of the Master thesis of $Y$. Goтo submitted to Miyazaki University in 1985.

\section{References}

1) Beuding, E. and W.H. Yale, Production of $\alpha-$ methylbutyric acid by bacteria free Ascaris lumbri- 


\section{ONODERA and Goto}

coides. J. Biol. Chem., $193: 411-423.1951$.

2) Bhatia, S.K., K. Pradhan and R. Singh, Ammonia anabolizing enzymes in cattle and buffalo fed varied nonprotein nitrogen and carbohydrates. J. Dairy Sci, 63: 1104-1108. 1980.

3) Bladen, H.A., M.P. Bryant and R.N. Doetsch, Production of isovaleric acid from leucine by Bacteroides ruminicola. J. Dairy Sci., 44 : 173-174. 1961.

4) Chalupa, W., Degradation of amino acids by the mixed rumen microbial population. J. Anim. Sci., 43 : 828-834. 1976.

5) Coleman, G.S., The metabolism of the amino acids of Escherichia coli and other bacteria by the rumen ciliate Entodinium caudatum J. Gen. Microbiol., 47 : 449-46 4. 1967.

6) Dehority, B.A., R.R. Johnson, O.G. Bentley and A.L. Moxon Studies on the metabolism of valine, proline, leucine and isoleucine by rumen microorganisms in vitro. Arch. Biochem. Biophys., 78: 15-27. 1958.

7) ONOdera, R. and M. Kandatsu, Conversion of lysine to pipecolic acid by rumen ciliate protozoa. Agric. Biol. Chem., 36 : 1989-1993. 1972.

8) ONODERA, R. and M. Kandatsu, Synthesis of lysine from $\alpha, \varepsilon$-diaminopimelic acid by mixed ciliated rumen protozoa. Nature, New Biol., 244: 31-32. 1973.

9) OnOdera, R. and M. Kandatsu, Formation of lysine from $\alpha, \varepsilon$-diaminopimelic acid and negligible synthesis of lysine from some other precursors by rumen ciliate protozoa. Agric. Biol. Chem., 38 : 913920. 1974
10) Onodera, R., T. Shinjo and M. Kandatsu, Formation of lysine from $\alpha, \varepsilon$-diaminopimelic acid contained in rumen bacterial cell walls by rumen ciliate protozoa. Agric. Biol. Chem., 38 : 921-926. 1974.

11) Onodera, R. and M. Kandatsu, Catabolism of lysine by mixed rumen bacteria. Agric. Biol. Chem., 39: 1239-1246. 1975.

12) ONODERA, R. and C. HENDERson, Growth factors of bacterial origin for the culture of the rumen oligotrich protozoon, Entodinium caudatum, J. Appl. Bacteriol., $48: 125-134.1980$.

13) Onodera, R. and T. Ushijima, Formation of 2aminobutanoic acid from threonine and methionine by mixed rumen ciliate protozoa, J. Protozool., 29 : 547 550. 1982

14) Onodera, R., Y. Yamaguchi and S. Morimoto, Metabolism of arginine, citrulline, ornithine and proline by starved rumen ciliate protozos. Agric. Biol. Chem., $47: 821-828.1983$.

15) Onodera, R. and R. Migita, Metabolism of threonine, methionine, and related compounds in mixed rumen ciliate protozoa. J. Protozool., 32: 326-330. 1985.

16) Onodera, R, Contribution of protozoa to lysine synthesis in the in vitro rumen microbial ecosystem. Appl. Environ. Microbiol., 51 : 1350-1351. 1986.

17) TsuborA, H. and S. Hoshino, Transaminase activity in sheep rumen content, J. Dairy Sci., 52 : 2024-2028. 1969.

18) Wakita, M. and S. Hoshino, A branched-chain amino acid aminotransferase from the rumen ciliate genus Entodinium. J. Protozool., 22 : 281-285. 1975. 


\title{
絶食ルーメン繊毛虫類による分枝アミノ酸の代謝
}

\author{
小野寺良次・後藤泰樹* \\ 宮崎大学農学部, 宮崎市 $889-21$ \\ *宮崎共立病院, 宮崎市 880
}

必須アミノ酸（ラット）のうち遊離の分枝アミノ酸（BCAA），フェニルアラニンおよびヒスチジン については，ルーメン織毛蝢による代謝様式がまだ知られていない，そこで，本研究では分枝了ミ， 酸を取り上げ、ルーメン織毛虫類によるそれらの代謝を検討した．

ヘイキューブおよび濃厚試料を給与している山羊（日本在来種）のルーメン内容物から常法により絏 毛虫類を採取し，洗浄後こ㧈を絶食条件下の抗生物質を含む緩衝液（MB 9) 中で， $39^{\circ} \mathrm{C} ， 6$ 時間イン キュベーションを行なって細菌の影響を除去した後, 再洗浄を行ない, ${ }^{14} \mathrm{C}$ 標識 BCAA 並びに抗生物 質を加えた MB 9 中で.さらに 12 時間インキュベーションを行なった。インキュベーション用容器と しては，中心井付きのワールブルグフラスコを用いた，インキュベーション前後に分析用試料を採取し， 遠心上清液および虫体加水分解物中のアミノ酸および遠心上清液中の揮発性脂肪酸（VFA）を定量し た.さらに，それらの放射能並びに $\mathrm{CO}_{2}$ 画分の放射能を液体シンチレーションカゥンターで測定した.

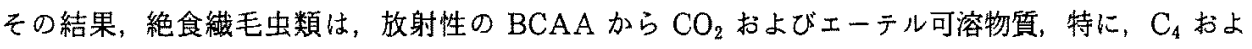
び $C_{5}$ のVFA を生成していることが分かった。本研究ではそれらのVFA を同定できなかったが, 過去のルーメン細菌などの結果加ら， $\mathrm{C}_{4}-\mathrm{VFA}$ はイソ酪酸でバリンから生成されると考えられた。 た， $\mathrm{C}_{5}$-VFA には，少なくとすイソ吉草酸および2ーメチル酪酸が含まれ，それぞれ，ロイシンおよび インロイシンから生成される上考えられた，さらに，BCAA の分解速度についても考察した。

日畜会報, $61(9): 843-849,1990$ 